\title{
Virulence Pattern of Pyricularia grisea Isolates from Farmers' Fields on Newly Released Upland Rice Cultivars
}

\author{
Leila G. Araújo ${ }^{1 *}$, Anne S. Prabhu ${ }^{1} \&$ Gisele B. da Silva² \\ 'Embrapa Arroz e Feijão, Cx. Postal 179, CEP 75375-000, Santo Antônio de Goiás, GO, fax (62) 533-2100, e-mails: \\ leilagarces@pop.com.br, prabhu@ cnpaf.embrapa.br; ${ }^{2}$ Departamento de Fitopatologia, Universidade Federal de Viçosa, \\ Avenida P.H. Rolfs s/n, Campus UFV, CEP 36570-000, Viçosa, MG, e-mail: giselebarata@vicosa.ufv.br
}

(Aceito para publicação em 07/07/2005)

Autor para correspondência: Anne Sitarama Prabhu

ARAÚJO, L.G., PRABHU, A.S. \& SILVA, G.B. Virulence pattern of Pyricularia grisea isolates from farmers' fields on newly released upland rice cultivars. Fitopatologia Brasileira 30:623-628. 2005.

\begin{abstract}
The virulence pattern of the isolates of Pyricularia grisea from commercial fields of the upland rice (Oryza sativa) cultivars 'Primavera' and 'BRS Bonança' was analyzed. A hundred and seventy monoconidial isolates of the pathogen virulent to 'Primavera' and 139 to 'BRS Bonança' collected from eight fields, during two years (2001-2003) were tested, under greenhouse conditions, on six newly released rice cultivars. Differences in virulence pattern were observed in pathogenic populations of 'Primavera' and 'BRS Bonança'. Isolates with virulence to improved cultivars were common in samples from farmers' fields in the absence of aloinfection. The virulence frequency of $P$. grisea isolates collected from 'Primavera"' to cultivars 'BRS Vencedora', 'BRS Colosso', 'BRS Liderança', 'BRS Soberana', 'BRS Curinga' and 'BRS Talento', was high in descending order. On the other hand, in the fungus population of 'BRS BRS Bonança' virulence frequency was high in 'BRS Talento', followed by 'BRS Curinga', 'BRS Vencedora', 'BRS Liderança', 'BRS Colosso' and 'BRS Soberana'. While virulence to 'BRS Talento' was rare among isolates from 'Primavera', it was most frequent in isolates of 'BRS Bonança'. The six improved rice cultivars permitted to differentiating agriculturally important virulences in the pathogen population which can be utilized in selecting breeding lines for specific resistance, in rice blast improvement program.
\end{abstract}

Additional keywords: Oryza sativa, Magnaporthe grisea, rice blast, physiologic races, resistance.

\section{RESUMO}

Padrão de virulência de isolados de Pyricularia grisea provenientes de lavouras de cultivares de arroz de terras altas recém lançadas

Foi analisado o padrão de virulência de isolados de Pyricularia grisea provenientes de lavouras de arroz (Oryza sativa) de terras altas das cultivares 'Primavera' e 'BRS Bonança'. Foram testados, em casa de vegetação, 170 e 139 isolados monospóricos virulentos às cultivares Primavera e BRS Bonança, respectivamente, coletados de oito lavouras, durante dois anos, 2001 e 2003, em seis cultivares recentemente lançadas. Foram observadas diferenças no padrão de virulência nas populações de 'Primavera' e 'BRS Bonança'. Isolados virulentos para novas cultivares foram comuns nas lavouras na ausência de aloinfecção. A freqüência de virulência de isolados de $P$. grisea coletados de 'Primavera' foi alta em ordem decrescente para as cultivares 'BRS Vencedora', 'BRS Colosso', 'BRS Liderança', 'BRS Soberana', 'BRS Curinga' e 'BRS Talento'. Por outro lado, na população do fungo da cultivar BRS Bonança, a frequiência de virulência foi alta em 'BRS Talento', seguido pela 'BRS Curinga', 'BRS Vencedora', 'BRS Liderança', 'BRS Colosso' e 'BRS Soberana'. Entre isolados coletados da cutivar Primavera, a virulência para 'BRS Talento' foi encontrada em baixa freqüência; porém foi freqüente para isolados coletados da cultivar BRS Bonança. As seis cultivares melhoradas permitiram estabelecer diferenças importantes em virulência nas populações do patógeno, que podem ser usadas na seleção de linhagens resistentes no melhoramento para esta característica.

Palavras-chave adicionais: Oryza sativa, Magnaporthe grisea, brusone, raças fisiológicas, resistência.

\section{INTRODUCTION}

Rice blast, caused by Pyricularia grisea (Cooke) Sacc. [= Magnaporthe grisea (T.T.Hebert) Yageshi \& Udagawa] is the major yield constraint in risk prone upland rice (Oryza sativa L.) in Brazil. One successful means of controlling plant diseases has been the development of cultivars with

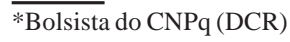

Fitopatol. bras. 30(6), nov - dez 2005 major or vertical resistance genes, because this type of resistance can be easily manipulated in a breeding program and is effective until the pathotypes of the pathogen to which it does not confer resistance become established (Flor, 1945). Despite the limited durability of this type of resistance, considerable progress has been made in reducing losses caused by rice blast, by planting cultivars with major resistance genes. Several upland rice cultivars such as 'BRS Colosso', 'BRS Curinga', 'BRS Liderança', 'BRS Soberana', 
'BRS Talento' and 'BRS Vencedora', developed for superior grain quality have been released in recent years. The improved rice cultivars often show greater resistance than old widely cultivated ones at the time of their release, but with increase in cultivated areas they become more susceptible. The advanced elite breeding lines before their release showed less disease severity than the cultivar Primavera under field conditions (Prabhu et al., 2003). Kiyosawa \& Shiyomi (1976) have shown that an increase of a certain pathotype as well as highly adapted isolates of blast pathogen in farmers' fields are closely correlated with the area of rice cultivar planted.

Race composition varies mostly with the cultivar, and different resistance genes present in the host are expected to exert selection pressure on the pathogen population. Different rice cultivars show a remarkable degree of differential reaction to the rice blast pathogen. In Brazil, previous studies were mostly concentrated on the determination of composition and frequency of occurrence of physiologic races in upland rice cultivars (Malavolta \& souza 1992; Cornélio, 2001; Prabhu \& Filippi, 2001; Filippi \& Prabhu, 2001; Prabhu et al., 2003). Most of the studies in Brazil and elsewhere, on the identification and prevalence of physiologic races were based on the samples collected in experimental plots or breeding nurseries. The number of virulence phenotypes among the isolates collected in these areas is generally greater than in commercial rice fields.

The pre-requisites for breeding blast resistant rice cultivars are: identification of resistance sources to the races compatible to the widely grown rice cultivars; knowledge of the performance of newly released cultivars to the predominant field isolates; and selection of differential isolates for combining resistance from different sources with the commercially acceptable cultivars. Differences were observed in virulence patterns of the isolates collected from 14 upland rice cultivars in experimental plots on 32 genotypes. The isolates from 'Primavera' were compatible on 'Primavera' and incompatible on 'BRS Bonança' and vice versa (Prabhu et al., 2002a). There is no information on the virulence frequency of $P$. grisea isolates from widely grown 'Primavera' and 'BRS Bonança' to improved rice cultivars.

The present investigation was undertaken to study the virulence pattern of $P$. grisea isolates from commercial rice fields of 'Primavera' and 'BRS Bonança' on newly released six upland rice cultivars.

\section{MATERIALS AND METHODS}

Isolates of $P$. grisea were collected from sporulating lesions on leaves of the cultivars Primavera and BRS Bonança, in eight farmers' fields in the State of Goiás, during two consecutive rice growing seasons, 2001/2002 and 2002/ 2003. Two rice fields of 'Primavera' were located in Santo Antônio de Goiás, one in Ceres and the other in Bela Vista, while those of the cv. 'BRS Bonança' were located in
Pirapitinga, Piracanjuba, Bela Vista and Uruana (Silva, 2005). Monoconidial isolates were obtained by directly transferring single spores on $5 \%$ water agar, in the majority of the cases from two to three lesions per leaf and one isolate per sporulating leaf lesion. These isolates were conserved on sterilized filter paper discs at $-20{ }^{\circ} \mathrm{C} \pm 1{ }^{\circ} \mathrm{C}$ in the refrigerator for subsequent tests.

A hundred and seventy isolates of $P$. grisea collected from 'Primavera' and 139 from 'BRS Bonança' were utilized for phenotypic virulence analysis in the present study. They were selected based on their virulence on the respective cultivars, Primavera and BRS Bonança. The virulence frequency of these isolates was tested under controlled greenhouse conditions on newly released upland rice cultivars such as 'BRS Colosso' (CNA 8989 - KAY BONNET/CNA 7119), 'BRS Curinga' (CNA 8812 CT9978-12-2-2P/CT10037-56-4-M-4-1P-1//P5589-1-1-3P1-1P/CT935), 'BRS Liderança' (CNA 8983 - KAY BONNET/CNA 7119), 'BRS Soberana' (CNA 8711 CUIABANA/CNAx1235-8-3//CNAs 6673)), 'BRS Talento' (CNA $_{\mathrm{s}} 8540$ - CT7244-9-1-5-3/CT6196-33-11-1-3// CT6946-2-5-3-3-2-M) and 'BRS Vencedora' (CNA 8817 CNA 6881/CNA 6886) along with 'Primavera' and 'BRS Bonança', besides eight standard international differentials ('Dular', 'Kanto 51', 'NP125', 'Raminad Str 3', 'Usen', 'Zenith', 'Caloro', 'Sha-tiao-tsao'). The test material was planted in plastic trays $(30 \times 15 \times 10 \mathrm{~cm})$ containing $3 \mathrm{~kg}$ of soil fertilized with $5 \mathrm{~g}$ of 5-30-15 (NPK) $+\mathrm{Zn}+3 \mathrm{~g}$ of ammonium sulfate. An additional $2 \mathrm{~g}$ of ammonium sulfate was applied 20 days after planting. Ten to 12 plants of each entry were sown in $0.3 \mathrm{~m}$ long rows totaling 16 rows per tray, eight on either side of the tray.

The monosporic isolates were multiplied on potatodextrose-agar for eight days. For sporulation, the isolates were grown on ground rice yeast extract agar (ground rice grain $15 \mathrm{~g}$, yeast extract $2 \mathrm{~g}$, agar $20 \mathrm{~g}$ per $1000 \mathrm{ml}$ of distilled water) in Petri dishes and incubated at $25{ }^{\circ} \mathrm{C}$ for seven days. The aerial mycelium was scrapped with a sterilized glass rod under aseptic conditions. The plates were later kept under fluorescent day light at $25{ }^{\circ} \mathrm{C} \pm 4{ }^{\circ} \mathrm{C}$ for four days with opem lids but covered with sterilized cheese cloth. Inoculum was prepared by flooding culture plates with distilled water and dislodging the conidia with a paint brush. The conidial suspension along with the scrapped mycelial fragments was filtered through a double layer of cheese cloth. The final conidial suspension was adjusted to $3 \times 10^{5}$ conidia per $\mathrm{ml}$ using a haemocytometer. Inoculation and evaluation procedures were as described in an earlier investigation (Filippi \& Prabhu, 2001). Leaf blast reaction was assessed seven to nine days after inoculation utilizing a 0-9 scale, where the lesion types 0,1 and 3 were considered as resistant or incompatible, and 4 to 9 as susceptible or compatible (International Rice Research Institute, 1988). Inoculation tests were repeated twice and in case of ambiguous or intermediate reaction by some isolates, the test was repeated again and only the ones that gave consistent and uniform 
reaction were utilized. A tray containing international and Brazilian differential hosts as non-inoculated control was maintained to ensure that no contamination occurred during the inoculation procedure.

The physiologic races were identified based on the reaction of eight standard international differentials (Atkins et al., 1967; Ling \& Ou, 1969). The virulence frequency in percentage, of isolates collected from 'Primavera' and 'BRS Bonança' was based on the total number of compatible reactions to each one of the six improved rice cultivars.

\section{RESULTS AND DISCUSSION}

The pathotype frequency varied between the two populations of 'Primavera' and 'BRS Bonança'. They represented seven (IA to IG) of eight international pathotype groups. Based on the reaction pattern of eight international differentials, 25 pathotypes were identified in a sample population of $170 \mathrm{P}$. grisea isolates collected from the rice cultivar Primavera. The predominant international pathotypes were IF-1 (33\%), ID-9 (15.3\%), IC-9 (11.7\%) and IC-25 (7.6\%). The pathotypes IB-57, IB-49 and IC-1 were represented by seven, six and five isolates, respectively. Eight pathotypes (IA-41, IB-21, IB-33, IB-41, IC-17, IC29, ID-10 and IF-2) were represented by single isolates, four pathotypes (IG-2, IB-25, IC-26 and ID-13) by two isolates, three pathotypes (IB-9, IE-1 and IG-1) by three isolates, and three other pathotypes (IB-1, IB-17 and ID-1) by four isolates. The most predominant races IC-1 and IB-9 reported in samples obtained from experimental fields in previous studies (Prabhu et al., 2003) were encountered in very low frequency, in commercial rice fields of 'Primavera'. Of the 139 isolates collected from 'BRS Bonança' from four sample sites, $125(89.9 \%)$ belonged to 20 pathotypes, the predominant ones being IB-41 (41.7\%) and IB-9 (30.2\%). Twelve pathotypes (IA-41, IB-37, IB-49, IB-57, IB-58, IB63, IG-1, IF-1, IC-1, IC-17, IC-9, IE-1) were represented by single isolates, one (IA-1) by two isolates, one (IB-61) by three isolates, two (IB-13, IB-1) by four isolates, and two other pathotypes (IB-33, IB-45) by seven isolates. The differences in pathotype structure of $P$. grisea isolates from 'Primavera' and 'BRS Bonança' reflect host specificity. Similar conclusions were drawn in earlier studies on pathotype diversity of $P$. grisea from improved upland rice cultivars in experimental plots (Prabhu et al., 2002a).

The conventional method of presenting the data on distribution of frequency of pathotypes or physiologic races is indirect and restricted only to the pathogenicity of the cultivars utilized as differentials. Virulent and avirulent isolates on given improved rice cultivars are sometimes characterized as the same race with international differentials. While the races yield important information in comparative studies, the identification of differential virulent isolates on new cultivars yields useful information for incorporating resistance genes. The data on virulence frequency and association of virulence, jointly with the races has applied value for directing the breeding program.

The virulence frequency of improved cultivars 'BRS Vencedora'(40.23\%), 'BRS Colosso'(4.02\%), 'BRS Liderança' (3.45\%), 'BRS Soberana' $(2.30 \%)$, 'BRS Curinga'(1.72\%) and 'BRS Talento'(1.15\%), was high in descending order, in $P$. grisea isolates collected from 'Primavera' (Figure 1A). While the virulence frequency to five of the six cultivars tested was low, ranging from 1.15 $\%$ to $4.02 \%$ the fungus population exhibited a high frequency to 'BRS Vencedora' (40.23\%). The isolates retrieved from the cultivar 'BRS Bonança' showed different order of ranking (Figure $1 \mathrm{~B}$ ).

Among the six upland rice cultivars tested, virulence to all six newly released cultivars was present in samples from both rice cultivars, but in different frequencies. Virulence to 'BRS Talento' was rare in test isolates from 'Primavera', but was highest in samples from 'BRS Bonança'. 'BRS Talento' is one of the most susceptible varieties in the field, but its susceptibility to only a few
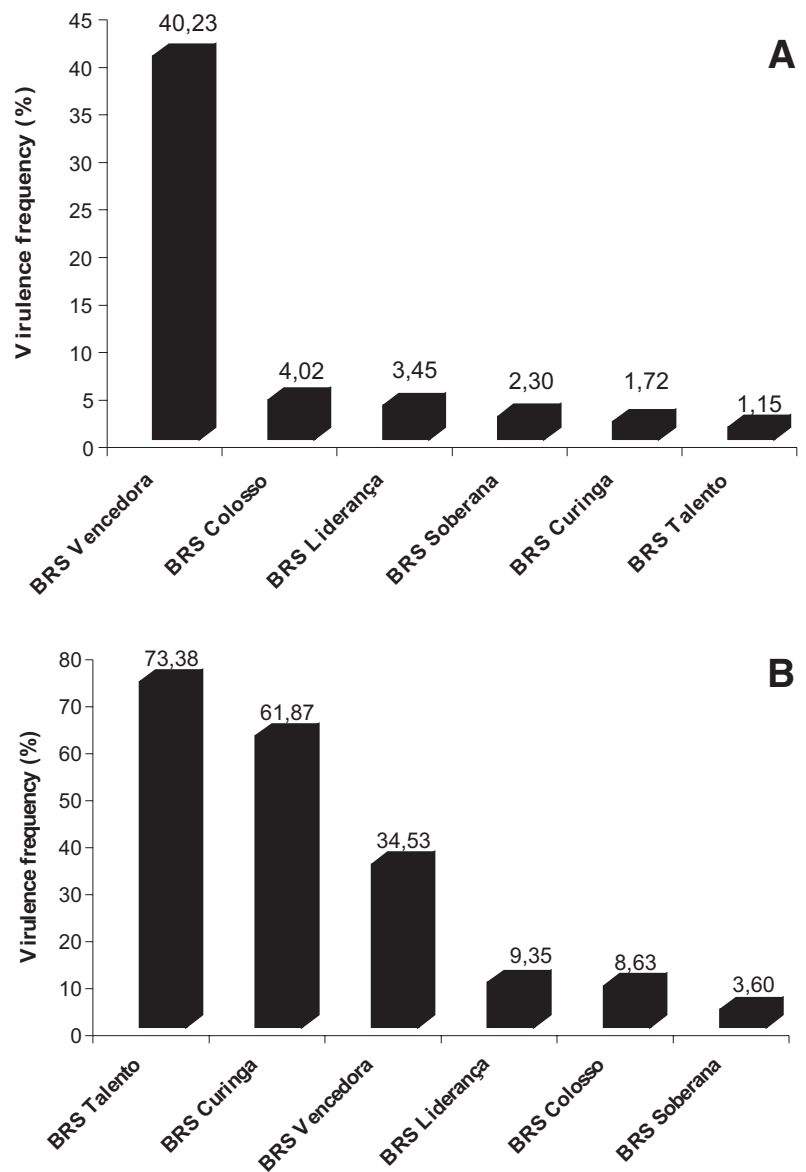

FIG. 1 - Virulence frequency of Pyricularia grisea isolates collected from farmers' fields of rice (Oryza sativa) cultivars 'Primavera' (A) and 'BRS Bonança' (B) to newly released upland rice cultivars. 
isolates from 'Primavera' was not expected. 'Primavera' is widely grown by upland rice farmers in west central Brazil and often shows high disease severity of leaf as well as panicle blast. On the other hand, the highest virulence frequency to isolates from 'BRS Bonança' to 'BRS Talento' shows a high degree of host influence on pathogen population structure. Seedling tests with specific isolates need not necessarily describe the field performance of the cultivars; possible reasons for high disease severities of 'BRS Talento' are presumably due to other factors such as greater susceptibility to panicle blast and a high frequency of virulence phenotypes. The level of leaf blast resistance of the lines 'BRS Curinga', 'BRS Talento' and 'BRS Liderança' in tests conducted in experimental plots under natural conditions of infection were found to be superior in
'Primavera' (Prabhu et al., 2003). In a breeding site where multiple pathotypes are present, the degree of field susceptibility of a line may not be a good indicator of the potential utility of the genes it carries. The cultivar ' BRS Talento' was highly susceptible in the field but showed resistance to specific isolates in inoculation tests.

Thirty-seven virulence patterns on six cultivars tested were observed among the isolates retrieved from 'Primavera' and 'BRS Bonança' (Table 1). Of 170 isolates from 'Primavera', 62 had similar virulence pattern, showing a susceptible reaction to 'BRS Vencedora' and a resistant reaction to five other cultivars. On the other hand, 56 of 139 isolates of 'BRS Bonança' showed a susceptible reaction to 'BRS Curinga' and 'BRS Talento' and a resistant reaction to the other four cultivars.

TABLE 1 - Reaction pattern of Pyricularia grisea isolates collected from farmer's fields of rice (Oryza sativa) cultivars 'Primavera' and 'BRS Bonança' on newly released cultivars

\begin{tabular}{|c|c|c|c|c|c|c|c|c|}
\hline \multirow{2}{*}{$\begin{array}{l}\text { Number of } \\
\text { virulence } \\
\text { pattern }\end{array}$} & \multicolumn{6}{|c|}{ "Rice Cultivars ${ }^{1}$} & \multicolumn{2}{|c|}{ Number of isolates ${ }^{2}$} \\
\hline & $\begin{array}{c}\text { BRS } \\
\text { Colosso }\end{array}$ & $\begin{array}{c}\text { BRS } \\
\text { Curinga }\end{array}$ & $\begin{array}{c}\text { BRS } \\
\text { Liderança }\end{array}$ & $\begin{array}{c}\text { BRS } \\
\text { Soberana }\end{array}$ & $\begin{array}{c}\text { BRS } \\
\text { Talento }\end{array}$ & $\begin{array}{c}\text { BRS } \\
\text { Vencedora }\end{array}$ & Primavera & $\begin{array}{c}\text { BRS } \\
\text { Liderança }\end{array}$ \\
\hline 1 & $\mathrm{R}$ & $\mathrm{R}$ & $\mathrm{R}$ & $\mathrm{R}$ & $\mathrm{R}$ & $\mathrm{R}$ & 93 & 16 \\
\hline 2 & $\mathrm{R}$ & $\mathrm{R}$ & $\mathrm{R}$ & $\mathrm{R}$ & $\mathrm{R}$ & $\mathrm{S}$ & 62 & 0 \\
\hline 3 & $\mathrm{R}$ & $\mathrm{R}$ & $\mathrm{S}$ & $\mathrm{R}$ & $\mathrm{R}$ & $\mathrm{R}$ & 2 & 1 \\
\hline 4 & $\mathrm{R}$ & $\mathrm{R}$ & $\mathrm{S}$ & $\mathrm{S}$ & $\mathrm{R}$ & $\mathrm{R}$ & 1 & 0 \\
\hline 5 & $\mathrm{~S}$ & $\mathrm{R}$ & $\mathrm{R}$ & $\mathrm{S}$ & $\mathrm{R}$ & $\mathrm{S}$ & 1 & 0 \\
\hline 6 & $\mathrm{~S}$ & $\mathrm{R}$ & $\mathrm{R}$ & $\mathrm{R}$ & $\mathrm{R}$ & $\mathrm{R}$ & 1 & 0 \\
\hline 7 & $\mathrm{~S}$ & $\mathrm{R}$ & $\mathrm{S}$ & $\mathrm{S}$ & $\mathrm{S}$ & $\mathrm{R}$ & 1 & 0 \\
\hline 8 & $\mathrm{~S}$ & $\mathrm{R}$ & $\mathrm{S}$ & $\mathrm{R}$ & $\mathrm{R}$ & $\mathrm{S}$ & 2 & 0 \\
\hline 9 & $\mathrm{R}$ & $\mathrm{S}$ & $\mathrm{R}$ & $\mathrm{R}$ & $\mathrm{R}$ & $\mathrm{R}$ & 1 & 0 \\
\hline 10 & $\mathrm{R}$ & $\mathrm{S}$ & $\mathrm{R}$ & $\mathrm{R}$ & $\mathrm{S}$ & $\mathrm{S}$ & 1 & 17 \\
\hline 11 & $\mathrm{R}$ & S & $\mathrm{R}$ & $\mathrm{R}$ & $\mathrm{R}$ & $\mathrm{S}$ & 1 & 1 \\
\hline 12 & $\mathrm{~S}$ & $\mathrm{R}$ & $\mathrm{R}$ & $\mathrm{R}$ & $\mathrm{R}$ & $\mathrm{S}$ & 2 & 1 \\
\hline 13 & $\mathrm{R}$ & $\mathrm{R}$ & $\mathrm{R}$ & $\mathrm{S}$ & $\mathrm{R}$ & $\mathrm{S}$ & 1 & 0 \\
\hline 14 & $\mathrm{R}$ & $\mathrm{R}$ & $\mathrm{R}$ & $\mathrm{S}$ & $\mathrm{R}$ & $\mathrm{S}$ & 1 & 0 \\
\hline 15 & $\mathrm{~S}$ & $\mathrm{R}$ & $\mathrm{R}$ & $\mathrm{R}$ & $\mathrm{S}$ & $\mathrm{S}$ & 0 & 2 \\
\hline 16 & $\mathrm{~S}$ & $\mathrm{R}$ & $\mathrm{R}$ & $\mathrm{S}$ & $\mathrm{S}$ & $\mathrm{S}$ & 0 & 1 \\
\hline 17 & $\mathrm{R}$ & $\mathrm{S}$ & $\mathrm{R}$ & $\mathrm{R}$ & $\mathrm{S}$ & $\mathrm{R}$ & 0 & 56 \\
\hline 18 & $\mathrm{R}$ & $\mathrm{R}$ & $\mathrm{S}$ & $\mathrm{R}$ & $\mathrm{S}$ & $\mathrm{R}$ & 0 & 1 \\
\hline 19 & $\mathrm{R}$ & $\mathrm{S}$ & $\mathrm{R}$ & $\mathrm{R}$ & $\mathrm{R}$ & $\mathrm{R}$ & 0 & 4 \\
\hline 20 & $\mathrm{R}$ & S & $\mathrm{S}$ & $\mathrm{R}$ & $\mathrm{S}$ & $\mathrm{S}$ & 0 & 1 \\
\hline 21 & $\mathrm{R}$ & $\mathrm{R}$ & $\mathrm{R}$ & $\mathrm{R}$ & $\mathrm{S}$ & $\mathrm{S}$ & 0 & 8 \\
\hline 22 & $\mathrm{R}$ & $\mathrm{R}$ & $\mathrm{R}$ & $\mathrm{R}$ & $\mathrm{S}$ & $\mathrm{R}$ & 0 & 1 \\
\hline 23 & $\mathrm{~S}$ & $\mathrm{~S}$ & $\mathrm{R}$ & $\mathrm{R}$ & $\mathrm{S}$ & $\mathrm{S}$ & 0 & 2 \\
\hline 24 & $\mathrm{~S}$ & $\mathrm{R}$ & $\mathrm{R}$ & $\mathrm{R}$ & $\mathrm{S}$ & $\mathrm{R}$ & 0 & 1 \\
\hline 25 & $\mathrm{~S}$ & $\mathrm{~S}$ & $\mathrm{R}$ & $\mathrm{R}$ & $\mathrm{S}$ & $\mathrm{R}$ & 0 & 4 \\
\hline 26 & $\mathrm{R}$ & $\mathrm{R}$ & $\mathrm{R}$ & $\mathrm{R}$ & $\mathrm{S}$ & $\mathrm{R}$ & 0 & 5 \\
\hline 27 & $\mathrm{R}$ & $\mathrm{S}$ & $\mathrm{S}$ & $\mathrm{R}$ & $\mathrm{R}$ & $\mathrm{S}$ & 0 & 1 \\
\hline 28 & $\mathrm{R}$ & $\mathrm{R}$ & $\mathrm{R}$ & $\mathrm{S}$ & $\mathrm{R}$ & $\mathrm{R}$ & 0 & 1 \\
\hline 29 & $\mathrm{R}$ & $\mathrm{R}$ & $\mathrm{S}$ & $\mathrm{R}$ & $\mathrm{R}$ & $\mathrm{S}$ & 0 & 2 \\
\hline 30 & $\mathrm{R}$ & $\mathrm{R}$ & $\mathrm{R}$ & $\mathrm{R}$ & $\mathrm{R}$ & $\mathrm{S}$ & 0 & 4 \\
\hline 31 & $\mathrm{R}$ & $\mathrm{R}$ & $\mathrm{S}$ & $\mathrm{R}$ & $\mathrm{S}$ & $\mathrm{S}$ & 0 & 2 \\
\hline 32 & $\mathrm{~S}$ & $\mathrm{R}$ & $\mathrm{S}$ & $\mathrm{R}$ & $\mathrm{R}$ & $\mathrm{S}$ & 0 & 1 \\
\hline 33 & $\mathrm{R}$ & $\mathrm{S}$ & $\mathrm{S}$ & $\mathrm{S}$ & $\mathrm{R}$ & $\mathrm{S}$ & 0 & 1 \\
\hline 34 & $\mathrm{R}$ & S & $\mathrm{R}$ & $\mathrm{S}$ & $\mathrm{R}$ & $\mathrm{S}$ & 0 & 1 \\
\hline 35 & $\mathrm{R}$ & S & $\mathrm{S}$ & S & S & $\mathrm{R}$ & 0 & 2 \\
\hline 36 & $\mathrm{R}$ & $\mathrm{S}$ & $\mathrm{R}$ & $\mathrm{S}$ & $\mathrm{S}$ & $\mathrm{R}$ & 0 & 1 \\
\hline 37 & $\mathrm{R}$ & $\mathrm{S}$ & $\mathrm{R}$ & $\mathrm{S}$ & $\mathrm{R}$ & $\mathrm{S}$ & 0 & 1 \\
\hline
\end{tabular}

$\mathrm{R}=$ resistant; $\mathrm{S}=$ susceptible reaction.

${ }^{2}$ Number of isolates collected from 'Primavera and 'BRS Bonança' showing similar reaction pattern on six rice cultivars. 
Ninety-three isolates from 'Primavera' and 16 from 'BRS Bonança' were avirulent to all six cultivars tested. Differential reaction to 'BRS Colosso' and 'BRS Liderança', which possibly carry the resistance genes from the same donor parent Keybonnet, was observed. The more appropriate and agriculturally useful phenotypic unit for resistance breeding program is the most predominant virulence phenotype on a given cultivar, rather than a pathotype. Zeigler et al. (1995) observed 71 distinct virulence patterns on 21 cultivars tested, and the determination of virulence pattern on improved rice cultivars well adapted to Brazilian upland conditions has implication in resistance breeding. Virulence to 'BRS Talento' and 'BRS Curinga' was strongly associated with the pathogen population of 'BRS Bonança'. Also, 17 isolates showed virulence associations to 'BRS Vencedora', 'BRS Curinga' and 'BRS Talento'. Some of these agriculturally important isolates that differed from each other can be utilized for incorporating resistance genes in commercial rice cultivars.

A great number of virulent isolates from both populations of rice cultivars 'Primavera' and 'BRS Bonança' showed type '4' reaction on cultivars tested (Table 2). These lesions are isolated, few in number, sporulating and typical of susceptible reaction, but not highly susceptible (5-9). However, some cultivars such as 'BRS Vencedora' showed highly susceptible reactions to isolates from 'Primavera', while 'BRS Talento', 'BRS Curinga' and 'BRS Vencedora' showed high susceptibility to pathogen populations from 'BRS Bonança'. The isolates virulent to genes in two or more cultivars furnish useful information in relation to frequency of association of virulence corresponding to resistance genes. The damage level of rice cultivars could change over time, not only because of change of race but also due to a gradual change in the aggressiveness of the blast isolate belonging to the same race or lineage (Ahn et al., 1996). The virulence pattern of isolates on the tested cultivars can vary with an increase in cultivated area over time. The cultivation of the six cultivars tested is relatively

TABLE 2 - Distribution of isolates of Pyricularia grisea collected from farmers' fields of rice (Oryza sativa) cultivars 'Primavera' and 'BRS Bonança', according to reaction type, in inoculation tests using six newly released cultivars

\begin{tabular}{|c|c|c|c|c|c|c|}
\hline \multirow{2}{*}{ Rice Cultivar } & \multicolumn{3}{|c|}{ 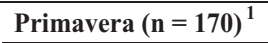 } & \multicolumn{3}{|c|}{$\overline{\text { BRS Bonança }(\mathrm{n}=170)^{1}}$} \\
\hline & $0-3^{2}$ & $4^{2}$ & $5-9^{2}$ & $0-3^{2}$ & $4^{2}$ & $5-9^{2}$ \\
\hline BRS Colosso & 163 & 2 & 5 & 127 & 4 & 8 \\
\hline BRS Curinga & 167 & 0 & 3 & 47 & 19 & 73 \\
\hline BRS Liderança & 164 & 1 & 5 & 127 & 0 & 12 \\
\hline BRS Sober ana & 165 & 2 & 3 & 131 & 4 & 4 \\
\hline BRS Talento & 168 & 0 & 2 & 35 & 18 & 86 \\
\hline BRS Vencedora & 99 & 21 & 50 & 93 & 15 & 31 \\
\hline
\end{tabular}

${ }^{1}$ Total number of isolates tested.

${ }^{2}$ Reaction type $0-3=$ resistant; $4=$ susceptible typical isolated elliptical sporulating lesions; $5-9=$ highly susceptible. recent compared to 'Primavera' and 'BRS Bonança'. The cultivar 'BRS Talento' was released in the 2002 rice growing season and the cultivars 'BRS Soberana' and 'BRS Colosso' were released in the 2003 rice growing season, whereas 'BRS Curinga' and 'BRS Liderança' are under field trials and will be released during 2004. Further studies on the virulence structure of the isolates collected from these six cultivars in farmers' fields can provide useful information on the changing pattern of virulence with increase in cultivated area.

Host genotype clearly has been shown to exert a strong selection pressure on $P$. grisea (Correa-Victoria \& Zeigler, 1993; Xia et al., 1993; Zeigler et al., 1994; Chen et al., 1995; Xia et al., 2000; Filippi et al., 2002; Prabhu et al., 2002b). Different resistance genes present in the host would be expected to exert selection on the pathogen population resulting in differential compatibility between cultivars and isolates (Prabhu \& Filippi, 2001). In upland rice, Filippi \& Prabhu (2001) showed that the cultivars from which the isolates are collected condition the virulence, independent of the collection site. It was interesting to see that this effect was clearly observed in samples of $P$. grisea isolates collected from breeders' plots of cultivars 'Primavera' and 'BRS Bonança', despite possible inter plot interference (Prabhu et al., 2002a). The present study has also shown strong host influence on virulence phenotypes, mainly in 'Primavera'.

The resistance level of the new upland rice cultivars to the pathogen population of the commercial rice cultivars 'Primavera' and 'BRS Bonança', allows breeders to anticipate changes in pathogen virulence. These cultivars possess different genes for resistance and the future upland rice cultivars can be improved by crossing these newly developed cultivars or by incorporating these genes into 'Primavera' and 'BRS Bonança' by conventional back cross method, using the differential isolates identified in this study.

\section{LITERATURE CITED}

AHN, S.W., MAKIHARA, D., IMBE, T., CHEN, D.H. \& BARROS, H.C. Population dynamics of Pyricularia grisea in rice cultivars with partial resistance. Phytopathology 11:646. 1996 (Abstract).

ATKINS, J.G., ROBERT, A.L., ADAAIR, C.R., GOTO, K., KOZAKA, T., YANAGIDA, R., YAMADA, M. \& MATSUMOTO, $\mathrm{S}$. An international set of rice varieties for differentiating races of Pyricularia oryzae. Phytopathology 57:297-301. 1967.

CHEN, D.H., ZEIGLER, R.S., LEUNG, H. \& NELSON, R.J. Population structure of Pyricularia grisea at two screening sites in the Philippines. Phytopathology 85:1011-1020. 1995.

CORNÉLIO, V.M.O. Identificação de patotipos de Pyricularia grisea Sacc., no arroz de terras altas em Minas Gerais, incidência e severidade da brusone e tipos de resistência. (Tese de Doutorado) Lavras. Universidade Federal de Lavras. 2001.

CORREA-VICTORIA, F.J. \& ZEIGLER, R.S. Pathogenic variability in Pyricularia grisea at a rice blast "hot-spot" breeding site in Eastern Colombia. Plant Disease 77:1029-1035. 1993. 
FILIPPI, M.C. \& PRABHU, A.S. Phenotypic virulence analysis of Pyricularia grisea isolates from Brazilian upland rice cultivars. Pesquisa Agropecuária Brasileira 36:27-35. 2001.

FILIPPI, M.C., PRABHU, A.S., ARAÚJO, L.G. \& FARIA, J.C. Genetic diversity and virulence pattern in field populations of Pyricularia grisea from rice cultivar Metica-1. Pesquisa Agropecuária Brasileira 37:1681-1688. 2002.

FLOR, H.H. The current status of the gene for gene concept. Annual Review of Phytopathology 9:275-296. 1945.

INTERNATIONAL RICE RESEARCH INSTITUTE. Standard evaluation system for rice. International rice testing program. $3^{\text {rd }}$ ed. Los Baños. International Rice Research Institute. 1988.

KIYOSAWA, S. \& SHIYOMI, M. Simulation of the process of breakdown of disease resistant varieties. Japan Journal of Breeding 26:339-352. 1976.

LING, K.C. \& OU, S.H. Standardization of the international race numbers of Pyricularia oryzae. Phytopathology 59:339-342. 1969.

MALAVOLTA, V.M.A. \& SOUZA, T.M.W. Variabilidade de Pyricularia oryzae no Estado de São Paulo. Summa Phytopathologica 18:287-290. 1992.

PRABHU, A.S. \& FILIPPI, M.C. Graus de resistência a brusone e produtividade de cultivares melhoradas de arroz de terras altas. Pesquisa Agropecuária Brasileira 36:1453-1459. 2001.

PRABHU, A.S., FILIPPI, M.C. \& ARAÚJO, L.G. Pathotype diversity of Pyricularia grisea from improved upland rice cultivars in experimental plots. Fitopatologia Brasileira 27:468-473. 2002a. PRABHU, A.S., FILIPPI, M.C., ARAÚJO, L.G. \& FARIA, J.C.
Genetic and phenotypic characterization of isolates of Pyricularia grisea from the rice cultivars Epagri 108 and 109. Fitopatologia Brasileira 27:566-573. 2002b.

PRABHU, A.S., FILIPPI, M.C., ARAUJO, L.G. \& BERNI, R.F. Resistance spectra of six elite breeding lines of upland rice to Pyricularia grisea. Pesquisa Agropecuária Brasileira 38:203-210. 2003.

SILVA, G.B. Estrutura populacional de Pyricularia grisea (Cooke) Sacc. em folha e panícula de arroz de terras altas. (Tese de Doutorado). Viçosa. Universidade Federal de Viçosa. 2004.

XIA, J.Q., CORRELL, J.C., LEE, F.N., MARCHETTI, M.A. \& RHOADS, D.D. DNA fingerprinting to examine micrographic variation in the Magnaporthea grisea (Pyricularia grisea) population in two rice fields in Arkansas. Phytopathology 83:10291035. 1993.

XIA, J.Q., CORRELL, J.C., LEE, F.N., ROSS, W.J. \& RHOADS, D.D. Regional population diversity of Pyricularia grisea in Arkansas and the influence of host selection. Plant Disease 84:877884. 2000.

ZEIGLER, R.S., CUOC, L.X., SCOTT, R.P., BERNARDO, M.A., CHEN, D.H., VALENT, B. \& NELSON, R.J. The relationship between lineage and virulence in Pyricularia grisea in the Philippines. Phytopathology 85:443-451. 1995.

ZEIGLER, R.S., TOHME, J., NELSON, R., LEVY, M. \& CORREA, F. Linking blast population analysis to resistance breeding: A proposed strategy for durable resistance. In: Zeigler, R.S., Leong, S.A. \& Teng, P.S. (Eds.) Rice Blast Disease. Wallingford. CAB International. 1994. pp.267-292. 